\title{
Omuz avasküler nekrozunda tanı ve tedavi
}

\section{Diagnosis and management of avascular necrosis of the shoulder}

\author{
Musa Uğur Mermerkaya ${ }^{1}$, Murat Birinci², Gazi Huri ${ }^{3}$ \\ 1Ankara Polatı Duatepe Devlet Hastanesi, Ortopedi ve Travmatoloji Bölümü, Ankara \\ ${ }^{2}$ Medipol Üniversitesi Hastanesi Tıp Fakültesi, Ortopedi ve Travmatoloji Anabilim Dalı, İstanbul \\ ${ }^{3}$ Hacettepe Üniversitesi Tıp Fakültesi, Ortopedi ve Travmatoloji Anabilim Dalı, Ankara
}

\begin{abstract}
Avasküler nekroz (osteonekroz), femur başından sonra en sık proksimal humerusta görülmektedir. Humerus başı beslenmesinin bozulmasına sebep olabilecek altta yatan birçok faktör olabilir. Bunlardan en sık karşılaşılanlar steroid kullanımı ve travmadır. Radyolojik görüntüleme, hastalığın evresini ve yayılımını belirleyip, tedavi algoritmasını belirlemede önemlidir. Tedavide primer amaç, hareket açıklığını koruyup, ağrısız bir ekleme sahip olmaktır. Tedaviye hastalığın evresine ve semptomların derecesine göre karar verilir. Erken evre hastalıkta fizik tedavi modiliteleri, farmakoterapi, kor dekompresyon ve artroskopi gibi seçenekler ön plandayken ilerleyen evrelerde birbirinden farklı artroplasti teknikleri uygulanabilmektedir. Uygun zamanda doğru tedavinin uygulanması hem hastalığın ilerlemesini engellemede, hem de hasta konforunun artırılmasında önemlidir.
\end{abstract}

Anahtar sözcükler: omuz eklemi; avasküler nekroz; osteonekroz; humerus başı; cerrahi tedavi
The humeral head is the second most common site of primary avascular necrosis (osteonecrosis) after the femoral head. There may be many underlying factors that may cause disruption of humeral head's blood supply. The most common etiologies are steroid use and trauma. Radiological imaging is important in determining the stage and extent of the disease and determining the treatment algorithm. The primary goal of treatment is to maintain range of motion and have a painless joint. Management of the treatment is depend on the stage of the disease and degree of the symptoms. While options such as physical therapy modifications, pharmacotherapy, core decompression and arthroscopy are at the forefront in early stage disease, different arthroplasty techniques can be applied in the later stages. Applying the right treatment at the appropriate time is important both in preventing the progression of the disease and increasing patient comfort.

Key words: shoulder joint; avascular necrosis; osteonecrosis; humeral head; surgical treatment

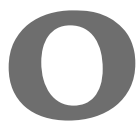
steonekroz (ON) subkondral kan dolaşımının kesilmesine sekonder olarak kemiğin hücresel bileşenlerinin ölümü ile karakterize dejeneratif bir kemik durumudur. Avasküler nekroz (AVN) olarak da bilinir ve tipik olarak ağırlık taşıyan eklemlerdeki uzun kemiklerin epifizini etkiler. ${ }^{[1]}$ ilerlemiş hastalıkta, subkondral çökmeye bağlı olarak dâhil olan eklemin canlılığı ve fonksiyonu bozulabilir (Şekil 1).

Femur başından sonra humerus başı en sık etkilenen ikinci bölgedir. ${ }^{[2]}$ Humerus, femur kadar yük alan bir bölge olmadığı için klinik semptomlar daha ileri evrelerde bulgu verebilmekte ve tanı koymakta geç kalınabilmektedir. Bu nedenle bu patoloji hafife alınmamalı, ortopedi ve travmatoloji alanındaki prensipler eşliğinde uygun bir yönetim sergilenmelidir.
Sonuç olarak humerus başı osteonekrozu, vaskülaritenin azalmasına sebep olabilecek travmatik ve atravmatik nedenlere bağlı olabilir. Tipik olarak travmatik nedenlere bağlı ON sebebi humerus proksimal çok parçalı kırıkları veya kırıklı çıkıklardır. ${ }^{[3]}$ Atravmatik nedenler arasında ise kortikosteroid tedavisi AVN'nin en sık sebebidir. Bu nedenle özellikle sistemik kortikosteroid tedavisi alan hasta popülasyonu yakından takip edilmelidir.

İzole humerus başı nekrozu nadir olarak görülür. Genellikle diğer eklemlerin, en sık da femur başının osteonekrozu ile beraber görülür. L'Insalata ve ark. humerus $\mathrm{ON}$ olan hastaları incelediklerinde, bu hastaların yaklaşık dörtte üçünde multifokal tutulum olduğunu göstermişlerdir. ${ }^{[3]}$

Humerus başı osteonekrozu riskini artıran değiştirilebilir ve değiştirilemeyen birçok risk faktörü mevcuttur.

- İletişim adresi: Dr. Murat Birinci, Medipol Mega Hastaneler Kompleksi, Göztepe Mah. Metin Sokak No:4, 34214 Bağcılar, İstanbul Tel: 0532 - 4233188 e-posta: murat-birinci@outlook.com

- Geliş tarihi: 11 Eylül $2020 \quad$ Kabul tarihi: 23 Eylül 2020 

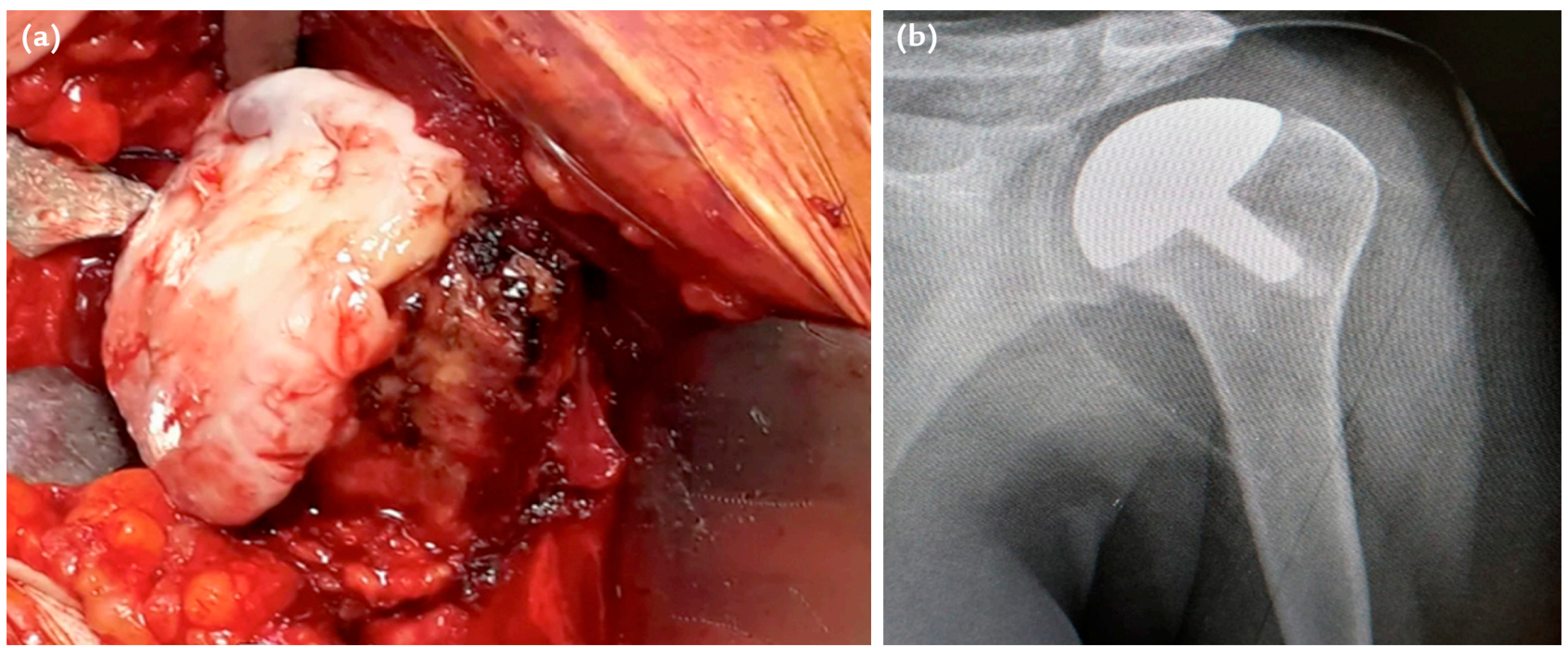

Şekil 1. a, b. Kırk beş yaşında erkek hasta, bilinmeyen etiyoloji. Ameliyat esnasında humerus başı AVN görüntüsü (a). Fokal resurfacing artroplasti sonrası direkt grafi (b).

\section{VASKÜLER ANATOMI}

Proksimal humerusun beslenmesini inceleyen birçok kadavra çalışması mevcuttur. Bu çalışmaların ortak amacı humerus başı osteonekrozu gelişimi ile vasküler hasar arasındaki ilişkiyi açıklamaktadır. Geçmiş yıllarda literatürdeki mevcut fikir birliği, humerus başının ana beslenmesinin anterior humeral sirkumfleks arterin anterolateral dalı tarafından olduğu yönünde olsa da ana beslenme posterior sirkumfleks arter tarafından sağlanmaktadır. Hettrich ve arkadaşları yaptıkları kadavra çalışmasında 24 omuzu karşılaştırmışlar. Humerus başını medial, lateral, superior ve inferior olarak dört parçaya bölüp, bir grupta anterior humeral sirkumfleks arteri, diğer grupta ise posterior sirkumfleks arteri ligate ederek Gadolinium enjekte edip manyetik rezonans (MR) görüntülerini incelediklerinde medial bölge hariç diğer üç bölgede posterior sirkumfleks arterin (PCA'nın) daha baskın olduğunu göstermişlerdir. ${ }^{[4]}$ Disseksiyon ve kırık tespiti sırasında posterior sirkumfleks arteri korumak proksimal humerus beslenmesini olumlu yönde etkileyip, ON riskini azaltır.

\section{EPIDOMIYOLOJi, RISK FAKTÖRLERI ve PATOGENEZ}

Humerus başı ON'si, erkekler arasında kadınlara göre yaklaşık iki kat daha sık görülür. Diğer yandan tedavisinde steroid kullanılan sistemik lupus eritematozus gibi otoimmun hastalıkların kadınlarda daha sık görüldüğü unutulmamalıdır. ON, her yaş grubunda görülebileceği gibi özellikle ikinci ve beşinci dekatta sıklığı artmaktadır. ${ }^{[3]}$
Etiyolojisinde travma, steroid kullanımı, orak hücreli anemi, sistemik lupus eritematozus, aşırı alkol kullanımı, Caisson hastalığı (vurgun hastalığı) ve Gaucher hastalığı gibi nedenler yer almaktadır (Tablo 1 ).

\section{Atravmatik Nedenler}

Kortikosteroid kullanımı humerus başı osteonekrozu için en sık görülen risk faktörü olarak göze çarpmaktadır. Patogenez tam olarak aydınlatılamamış olsa da

Tablo 1. Omuz avasküler nekroz etiyolojisinde yer alan başlıca faktörler

\begin{tabular}{|c|c|}
\hline Atravmatik nedenler & Travma sonrası nedenler \\
\hline Kortikosteroid kullanımı & $\begin{array}{l}\text { Kırık nedenli proksimal humerus } \\
\text { beslenmesinin bozulması }\end{array}$ \\
\hline Alkolizm & İyatrojenik direkt vasküler hasar \\
\hline $\begin{array}{l}\text { Hemoglobinopatiler } \\
\text { (orak hücreli anemi, } \\
\text { talasemi) }\end{array}$ & \\
\hline $\begin{array}{l}\text { Vurgun hastalı̆̆ı } \\
\text { (Caisson hastalığı) }\end{array}$ & \\
\hline Vaskülitler & \\
\hline Radyasyon-ilişkili nedenler & \\
\hline $\begin{array}{l}\text { Depo hastalıkları } \\
\text { (Gaucher hastalığı) }\end{array}$ & \\
\hline İdiyopatik & \\
\hline
\end{tabular}




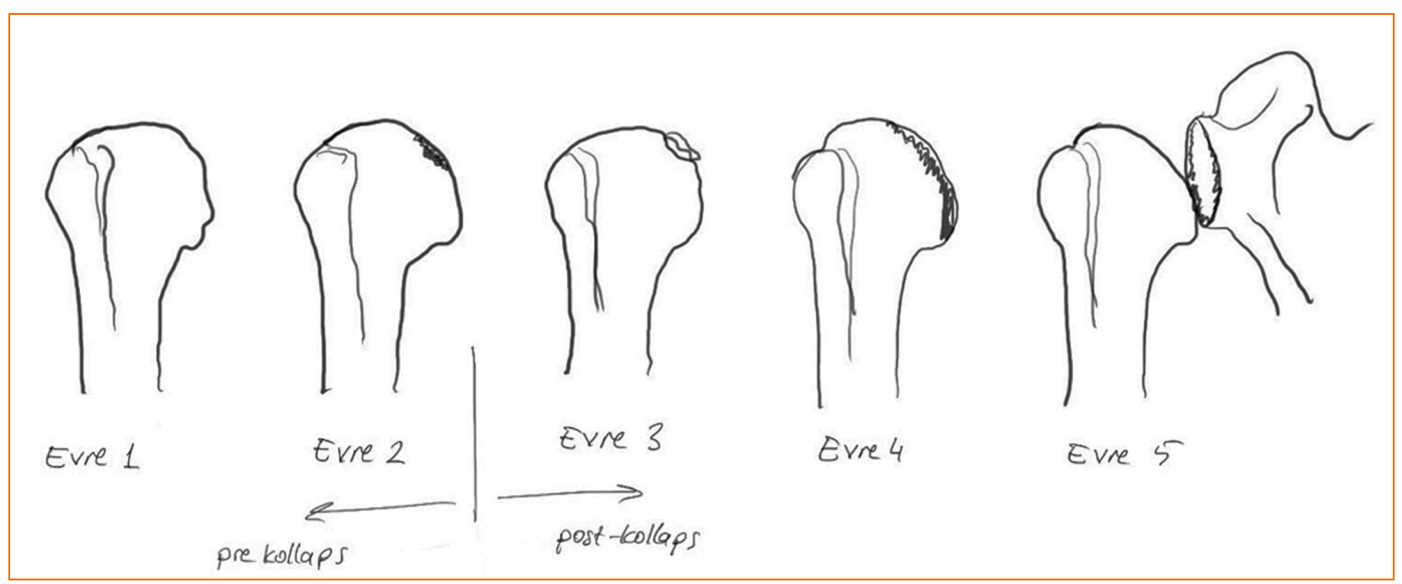

Şekil 2. Cruess humerus başı avasküler nekroz sınıflandırması.

adiposit hipertrofisine bağlı artmış interosseöz basıncın humerus başında lokal iskemiye neden olduğu düşünülmektedir. ${ }^{[5]}$ Her ne kadar genel bilgi steroid kullanımı sonrası 6-18 ayda şikayetlerin başladığı yönünde olsa da literatürde akut olgularda bildirilmiştir.

Lipit depo hastalı̆̆ı olan Gaucher hastalığında da artmış yağ asidi miktarı arteriollerde lokal hasar meydana getirip avasküler nekroza neden olabilmektedir. ${ }^{[5]}$ Sistemik dolaşımdaki lipit miktarının artması birçok bölgeyi etkileyip multifokal hastalığa sebep olabilir. Literatürde eklem içine steroid enjeksiyonu sonrası gelişen humerus başı osteonekrozları da bildirilmiştir. ${ }^{[6]}$

Alkolizm, kortikostreoidlerle benzer bir mekanizma üzerinden humerus başı osteonekrozuna sebep olabilir. Etilen alkolün aşırı yıkımı sonrası oluşan NADH (indirgenmiş nikotinamid adenin dinükleotid), karaciğerde yağ asitlerinin artmasına ve bunların kan dolaşımına sızmasına sebep olur. Artan sistemik lipit seviyeleri subkondral kemiğe embolize olup bu bölgenin avasküler kalmasına sebep olabilir. Venöz staz artar, böylece ostenonekroz daha da ilerler. ${ }^{[7]}$

Hemoglobinopatiler, özellikle de orak hücreli anemi, humerus başı osteonekrozu için sık bilinen bir risk faktörüdür. Oraklaşmış hücreler küçük arteriollerde birikerek mikroinfarktüslere neden olur. Orak hücre anemili hastalarda artmış viskosite de patogenezde rol oynayan faktörlerden biridir. Ayrıca humerus başı AVN olan hastaların yaklaşık \%75'inde femur başı AVN birlikteliği olduğunu bildiren yayınlar da mevcuttur. ${ }^{[8]}$

\section{SINIFLAMA}

Osteonekroz evrelemesi önemlidir, çünkü tedavi evreye göre değişmekte ve tedaviye yanıt büyük ölçüde hastalığın evresi ile korelasyon göstermektedir. Omuz AVN'de en çok kullanılan sınıflandırma sistemi Cruess tarafından tanımlanmıştır. ${ }^{[9]}$ Cruess daha önce Ficat tarafından femur başı osteonekrozu için kullanılan sistemi modifiye etmiştir.

Evre 1 hastalıkta direkt grafide değişiklik yoktur. MR ile görüntülemede değişiklikler görülebilir. Evre 2'de kollaps olmadan erken radyografik değişiklikler görülebilir. Tipik olarak humerus başı merkezinin superioründe kırık ile birlikte olmayan sklerotik değişiklikler izlenebilir. Evre 3'te humerus başı osteonekrozu için patognomonik olan kresent bulgusu görülebilir. Bu işaret subkondral kemiğin çökmeye başlayıp, kıkırdak dokudan ayrıldığının göstergesidir. Bu basamakta artık kollaps başlamıştır. En iyi üst kol eksternal rotasyondayken çekilen anterior-posterior direkt grafilerde görülebilir. Kartilaj hasarına bağlı eklem içinde eklem faresi bulunabilir ve mekanik semptomlara sebep olabilir. Evre 4'te ise etkilenen bölgede diffüz nekroz ve subkondral kollaps ile birlikte ileri artrit eşlik eder. Evre 5'te ise evre 4'teki hastalığa glenoid artiküler yüzde tutulum eşlik eder (Şekil 2).

\section{KLINIK}

Klinik muayene ve ayrıntılı bir anamnez osteonekroz etiyolojisini belirlemek açısından oldukça önemlidir. Değiştirilebilen ve değiştirilemeyen faktör iyice irdelenmelidir. Hastalığın multifokal olabileceği unutulmamaIıdır. Etiyolojiye hâkim olmak diğer eklem girişimlerini de minimalize etmek açısından önemlidir. Humerus, femur kadar yük alan bir eklem olmadığı için klinik daha sinsi seyredip ileri dönemde bulgular ortaya çıkabilir. Osteonekroz genellikle superomedial bölümde başladığı için genellikle $90^{\circ}$ fleksiyon ve $60^{\circ}$ abduksiyon ile artan ağrı omuz AVN yönünden şüphelendirmelidir. Ağrııı şiddetlendirecek baş üstü aktiviteleri 
azaltılmalıdır. Etiyolojik faktörlerde göz önüne alınarak progresif ağı ve omuz hareketlerinde kısıtlılık varlığında avasküler nekroz seçeneği akla gelmeli ve görüntüleme yöntemleri ile tanı desteklenmelidir. ${ }^{[10]}$

\section{GÖRÜNTÜLEME}

ilk tercih direkt grafilerdir. Bulgular femur başı osteonekrozundakilere benzerdir. Gerçek ön-arka grafiler, superior-inferior aksiller grafiler (glenohumeral eklem yüzü), internal ve eksternal rotasyon grafileri (humerus başı projeksiyonu) tercih edilmektedir. Direkt grafilerdeki değişimlerin hastalığın ileri evrelerinde görüldüğü akılda bulundurulmalıdır.

MR, kemik iliğindeki yağ ve su içeriğindeki değişikliklere direkt grafilere göre daha duyarlıdır. Nekroze ve kanlanan doku arasındaki farkı diğer yöntemlere göre daha net bir şekilde ortaya koyar. Tanıda diğer görüntüleme yöntemlerine göre üstündür. ${ }^{[11]}$

Kemik sintigrafinin tarihsel olarak ON tanısında önemli bir yeri bulunmasına rağmen son dönem yapılan çalışmalarda humerus osteonekrozu tanısında duyarlılığının düşük olduğunu, büyük kemik lezyonların \%58'ini belirleyebildiği bildirilmektedir. ${ }^{[12]}$ MR ve kemik sintigrafiyi karşılaştıran bir çalışmada patolojik olarak kanıtlanmış 30 omuz ON lezyonunun tamamı MR ile belirlenebilmişken, sadece 10 (\%33) tanesi kemik sintigrafide tespit edilebilmiştir. ${ }^{[13]}$

\section{TEDAVi}

Osteonekroz tedavisindeki amaç ağrıyı azaltmak, eklem hareket açıklığını korumak ve progresyonu engellemektir. Tedavi yöntemleri semptomların derecesine ve hastalığın evresine göre değişiklik göstermektedir.

\section{Cerrahi Olmayan Tedavi Seçenekleri}

Alkol ve sigara gibi etiyolojide rol alan faktörlerden uzaklaşmak, steroid kullanımı olan hastaların mümkünse alternatif olan ilaçları kullanması hem proksimal humerus ON ilerleyişini azaltıp hem de diğer etkilenmemiş eklemlerin korunmasını sağlayabilir. Risk faktörlerinin değerlendirilmesine ek olarak hastalara eklem katılığını önlemek için hareket açıklığını koruyucu ve omuz kuşağı kaslarının güçlendirilmesini içeren, kullanılmamaya bağ|ı adhesiv kapsülit oluşumunu engelleyici fizik tedavi egzersiz programları düzenlenmelidir. ${ }^{[14]}$ Erken evre, humerus başının biyomekanik kompresyonunun henüz gelişmediği hastalarda ağrı kesici anti-enflamatuvar ilaçlara ek olarak, revaskülarizasyona izin veren ve yeni kemik gelişimini uyarıcı prostasiklinler, vazodilatörler, bisfosfonatlar ve lipit düşürücü ajanların kullanımı gündemdedir. Ancak bunların etkinliği ve güvenirliliği ile ilgili çalışmalar henüz yeterli değildir. ${ }^{[15]}$

\section{Cerrahi Tedavi Seçenekleri}

\section{Kor dekompresyon}

Osteonekrozun erken evrelerinde intraosseöz basıncı azaltmak ve neovaskülarizasyonu uyarmak için uygulanan tedavi seçeneklerinden biridir. Femur başı ON'da yaygın olarak uygulanan bu yöntemin, humerus başı ON'daki sonuçlarını inceleyen birçok çalışma bulunmaktadır. Genel olarak evre 1 ve 2'de kor dekompresyon uygulanan hastalarda ağrı ve fonksiyonel skorların iyiye gittiği, artroplasti ihtiyacının geciktiği veya ortadan kalktığı görülmüştür. ${ }^{[3,12,15-17]}$

Mont $^{[13]}$ ve Harreld ${ }^{[15]}$, geriye dönük olarak evre 1 ve 2 hastalığı kor dekompresyon ile tedavisinde \%100; La Porte ve ark. ${ }^{[17]}$, evre 1 ve 2 hastalıkta \%94 ve $\% 88$ başarı sağlamışlarken; Kennon ve ark. ${ }^{[16]}$, kor dekompresyon uygulanan orak hücre anemili evre 1 ve 2 hastaların tümünde ve kortikosteroid kullanımına bağlı AVN gelişen erken evre (1-2) hastaların $\% 50$ 'sinde 2 yıl içinde artroplasti gereksinimi olduğunu bildirmişlerdir.

Evre 3 hastalıkta Mont ve ark. ${ }^{[13]}, 10$ hastanın yedisinde; La Porte ve ark. ${ }^{[18]}$ ise 23 hastanın 16'sında başarılı sonuçlar bildirmişlerdir. Kor dekompresyonun evre 3 omuz ON'daki başarı oranları evre 3 femur başı ON'a göre daha iyi olarak göze çarpmaktadır. ${ }^{[18]}$ Bunun nedeni omuzun daha az yük taşıyan bir eklem olması olabilir.

$\mathrm{Bu}$ teknik perkütanöz olarak ${ }^{[14]}$, artroskopik yardımlı[19] ve deltopektoral yaklaşımla bisipital oluğun lateralinde kalacak şekilde açık olarak ${ }^{[13]}$ uygulanabilmektedir. Günümüzde daha çok perkütanöz yöntem tercih edilmektedir. Bu yöntemde 2,7 veya 3,2 mm'lik Kirshner teli perkütanöz olarak, floroskopi kontrolünde istenilen epifiziyel bölgeye kadar gönderilir. Kılavuz (guide) tel üzerinden drilleme işlemi yapılır (önerilen küçük lezyonlar için iki, büyük lezyonlar için üç faklı geçiş yeri). ${ }^{20]}$ isşlem açık cerrahilere göre daha az morbiditeye sahiptir. Ameliyat sonrası dönemde üç gün omuz kol askısı, sonrasında aktif yardımlı fleksiyon, abduksiyon ve tolere edebildiği kadar rotasyonel hareketler başlanır. 5. haftada hasta asemptomatikse günlük aktivitesini yerine getirebilecek tüm hareketlere izin verilir. ${ }^{[15]}$

\section{Artroskopi}

Osteonekrozun daha ileri aşamalarında artroskopi seçeneği gündeme gelebilir. ON'un ilerlemesini engellemekten ziyade mekanik semptomların giderilmesine yardımcı olur. Artroskopik serbest cisim çıkarılması, sinoviyektomi, debridman ve kondral fleplerin temizlenmesi sonucu ağrı ve fonksiyonel skorların arttığını gösteren yayınlar literatürde mevcuttur. ${ }^{[21]}$ 

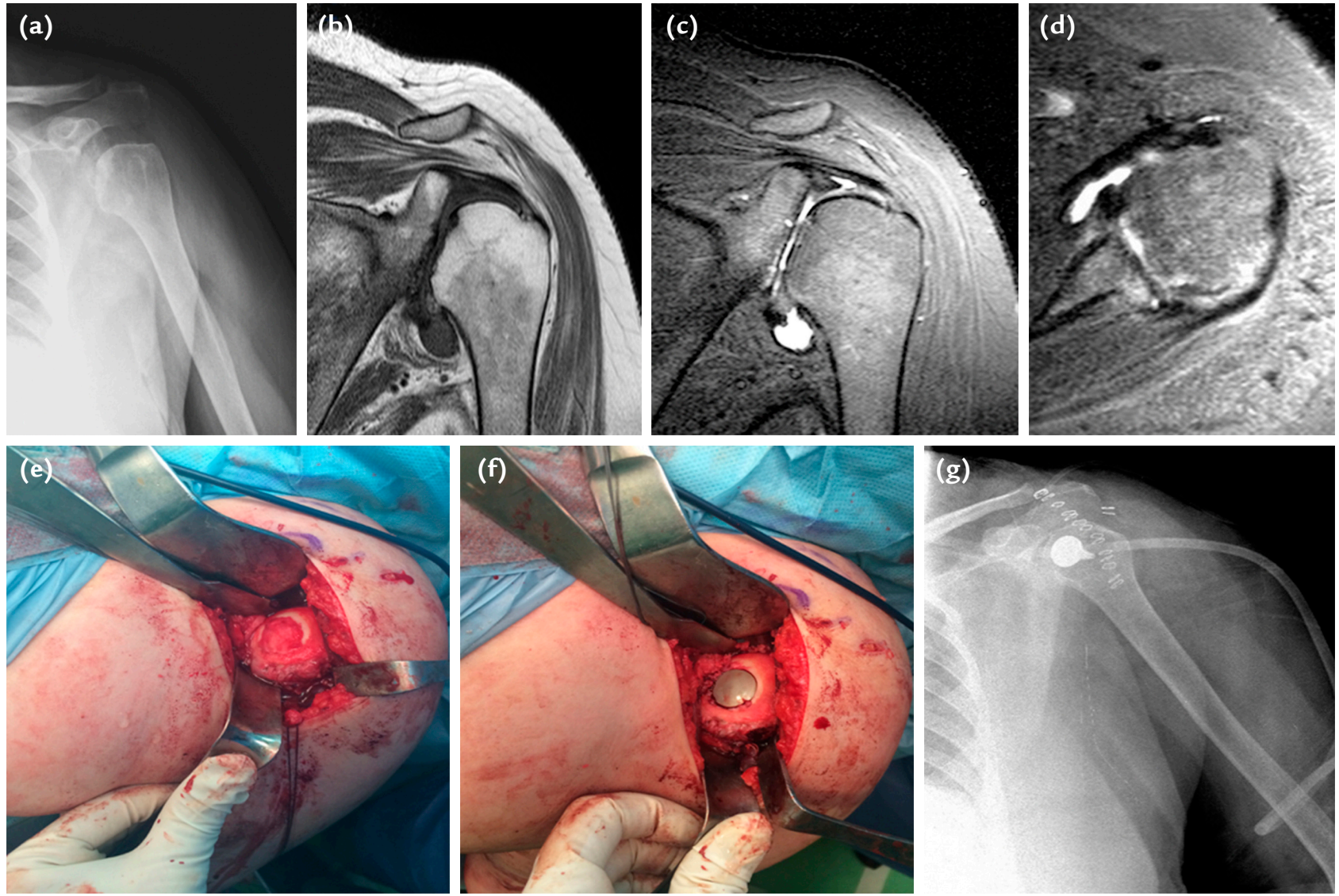

Şekil 3. a-g. Elli dört yaşında erkek hasta, omuz eklemine tekrarlayan steroid enjeksiyonu uygulanması sonrası gelişen humerus başı osteonekrozu: ameliyat öncesi direkt anterior-posterior grafisi (a); ameliyat öncesi omuz osteonekroz koronal ve aksiyel MR görüntüleri (b-d); fokal kıkırdak lezyonu temizlenip humerus başı implant için uygun hale getirildiğini gösteren, ameliyat esnasında görüntü (e); implant tespiti sonrası humerus başının ameliyat esnasında görüntüsü (f); implant tespiti sonrası humerus başının ameliyat sonrası direkt grafi görüntüsü $(\mathrm{g})$.

\section{Greftleme}

Nekrotik dokunun çıkarılması ve yerine ya kansellöz ve kortikal otogreft ya da vaskülarize kemik grefti uygulanması işlemidir. Replase edilen nekrotik kemik sayesinde artiküler yüzeyin çökmeyi engelleyecek ve kemik oluşumuna izin verecek bir mekanik destek sağlanır. ${ }^{[15]}$ Genelde evre 3 ve 4 hastalık tedavisinde uygulanır. Literatürde farklı iliak krest ${ }^{[15]}$, skapula[ ${ }^{[22]}$ ve otolog humerus başı gibi farklı donör bölgelerinden greftleme işlemleri tariflenmiştir. 2 yıllık sonuçlarda ağrı ve fonksiyonel skorlarda iyileşme görülse de, evre 3 ve 4 hastalıkta greftleme işleminin uzun dönemde artroplastiye göre üstünlüğünü gösteren yeterli kanıtlar henüz mevcut değildir. ${ }^{[22,23]}$

\section{Artroplasti}

Kollapsın gerçekleştiği (evre 3 ve üstü) hastalarda artroplasti seçeneği ele alınmalıdır. Artroplasti, sadece fokal eklem yüzünün replasmanı şeklinde yapılabileceği gibi tüm glenohumeral eklemin replasmanın yapılabileceği geniş bir tedavi seçeneği sunar. Replasmanın boyutuna kararı vermede, lezyonun evresi, hastanın yaşı, beklentisi, rotator kılıf kaslarının sağlamlığı ve mevcut deformite belirleyicidir. Tüm omuz artoplastilerinin yaklaşık \%5’i avasküler nekroz nedeniyle uygulanmaktadır.

Fokal resurfacing (eklem yüzü replasmanı): Humerus başı fokal eklem yüzü replasmanı sayesinden bir yandan kemik stok diğeryandan mevcut inklinasyon, off-set, başşaft açısı korunur. Aynı zamanda ileride bir revizyon cerrahisinde kolaylık sağlar. Genellikle tam veya tama yakın artiküler kartilaj hasarı mevcut, kor dekompresyon ve artroskopik tedavilere yanıt vermeyen evre 3 hastalıkta uygulanır. Tespiti sağlayacak yeterli epifıziyel kemik stok bulunmalıdır. ${ }^{[24]}$ Soudy ve ark., fokal eklem yüzü replasmanı yaptıkları 105 omuzu, ortalama 56 ay (24-120) takip etmişler. Bu hastalardan altısına ON nedenli cerrahi tedavi uygulanmış. Constant skorunun 36'dan 64'e çıktığı izlenmiş (Şekil 3). ${ }^{25]}$ 
Hemiartroplasti (HA), total omuz artroplastisi (TOA) ve ters omuz artroplastisi (ters TOA): Genellikle yeterli kemik stok olmayan evre 3 hastalık ve evre 4 hastalıkta uygulanmaktadır. Glenoidal tutulum olan evre 5 hastalıklarda total omuz artroplastisi ve ters omuz artroplastisi seçenekleri gündeme gelir.

Hemiartroplastinin hem cerrahi olarak daha kolay uygulanabilir olması, operasyon süresinin daha kısa olması, daha az instabilite problemleri meydana gelmesi hem de total artoplastiye revizyon şansının olması evre 4 hastalıkta daha çok tercih edilmesine neden olmaktadır. ${ }^{[26]}$

Her üç seçenek içinde genellikle deltopektoral yaklaşım tercih edilir. Ters omuz artoplastisi dışındaki tedavi seçeneklerinde rotator kılıf ve deltoid yetmezliğinin olmaması gerekmektedir. Subskapularis kası yapışma yerinden ayrıldıktan sonra işlem sonrası cerrahın tercihine göre ya tendon-tendon ya da kemik-tendon iyileşmeye uygun olacak şekilde tamir edilir. Ameliyat sonrası 3 hafta eğitimli bir terapist eşliğinde pasif ROM hareketler verilir. Sonraki 3 hafta internal rotasyonu kısıtlı olacak şekilde (subscapularis iyileşmesi için) aktif-yardımlı fizik tedavi protokolüne geçilir. Altı hafta sonra aktif hareket başlanır. ${ }^{[27]}$

Literatürde HA ve TOA sonuçlarını karşılaştıran büyük olgu serileri mevcuttur. Sperling ve ark., 50 yaş altında osteonekroz nedeni ile HA ve TOA yapılan hastaları incelemişler ve 15 yıllık implant sağkalımını \%73 (HA) ve \%84 (TOA) olarak bulmuşlardır. ${ }^{[28]} \mathrm{Her}$ iki yöntemde de ağrı belirgin şekilde gerilemiş ve eklem hareket açıklığı belirgin şekilde artmıştır. Özellikle genç hastalarda humeral komponent kemik stoğu korumak için press-fit şekilde uygulanmalıdır. Mansat ve ark., ortalama 7 yıl takip ettikleri HA ve TOA yapıIan 19 hastanın 16'sında tatmin edici klinik sonuçlar almışlardır. Son takiplerinde TOA yapılan hastaların $3 / 5$ 'inde glenoidal komponent gevşemesi ve HA yapılan hastaların 2/14'ünde glenoid ağrısı tarif etmişlerdir. ${ }^{[29]}$ Feely ve ark., TOA ve HA yapılan 64 omuzu karşılaştırdıklarında komplikasyon oranın TOA'da daha fazla olduğunu (\%22 vs \%8) bildirmişlerdir. ${ }^{[30]}$

\section{SONUÇ}

Humerus başı osteonekrozu ağrıya ve omuz disfonksiyonuna neden olan önemli bir morbidite nedenidir. Humerus başı osteonekroz patogenezi, ilişkili risk faktörleri halen tam olarak anlaşılamamıştır ve çeşitlilik gösteren, kompleks bir tedavi algoritmasına sahip lezyonlardır. Akla gelmesi gereken birçok etiyolojik neden olduğu, hastanın yaşına, yapısına ve hastalığın evresine bağlı olarak değişen semptomlar görülebileceği unutulmamalıdır. Erken tanı, tedavi etkinliği artırmaktadır.
Genel olarak bakıldığında, ilk olarak erken evre hastalıkta cerrahi dışı tedavi seçenekleri tercih edilirken, semptomatik evre 1-2 hastalıkta kor dekompresyon uygulanabilir. Eklem içi patolojiler eşlik etmeye başladığında artroskopi yardımlı cerrahi seçenekler gündeme gelebilir. İleri evre hastalıkta artoplasti modiliteleri akılda bulundurulmalıdır.

\section{KAYNAKLAR}

1. Shah KN, Racine J, Jones LC, Aaron RK. Pathophysiology and risk factors for osteonecrosis. Curr Rev Musculoskelet Med 2015;8(3):201-9. Crossref

2. Hasan SS, Romeo AA. Nontraumatic osteonecrosis of the humeral head. J Shoulder Elbow Surg 2002;11(3):281-98. Crossref

3. L'Insalata JC, Pagnani MJ, Warren RF, Dines DM. Humeral head osteonecrosis: clinical course and radiographic predictors of outcome. J Shoulder Elbow Surg 1996;5(5):35561. Crossref

4. Hettrich CM, Boraiah S, Dyke JP, Neviaser A, Helfet DL, Lorich DG. Quantitative assessment of the vascularity of the proximal part of the humerus. J Bone Joint Surg Am 2010;92(4):943-8. Crossref

5. Hungerford DS, Lennox DW. The importance ofincreased intraosseous pressure in the development of osteonecrosis of the femoral head: implications for treatment. Orthop Clin North Am 1985;16(4):635-54. https://pubmed.ncbi.nlm. nih.gov/3903603/

6. Dilisio MF. Osteonecrosis following short-term, lowdose oral corticosteroids: a population-based study of 24 million patients. Orthopedics 2014;37(7):e631-6. Crossref

7. Chang CC, Greenspan A, Gershwin ME. Osteonecrosis: current perspectives on pathogenesis and treatment. Semin Arthritis Rheum 1993;23(1):47-69. Crossref

8. Milner PF, Kraus AP, Sebes JI, Sleeper LA, DukesKA, Embury $\mathrm{SH}$, Bellevue R, Koshy M, Moohr JW, Smith J. Osteonecrosis of the humeral head in sickle cell disease. Clin Orthop Relat Res 1993;(289):136-43. Crossref

9. Cruess RL. Experience with steroid-induced avascular necrosis of the shoulder and etiologic considerations regarding osteonecrosis of the hip. Clin Orthop Relat Res 1978;(130):86-93. Crossref

10. Patel S, Colaco HB, Elvey ME, Lee $\mathrm{MH}$. Post-traumatic osteonecrosis of the proximal humerus. Injury 2015;46(10):1878-84. Crossref

11. Lee JA, Farooki S, Ashman CJ, Yu JS. MR patterns of involvement of humeral head osteonecrosis. J Comput Assist Tomogr 2002;26(5):839-42. Crossref

12. Mont MA, Ulrich SD, Seyler TM, Smith JM, Marker DR, McGrath MS, Hungerford DS, Jones LC. Bone scanning of limited value for diagnosis of symptomatic oligofocal and multifocal osteonecrosis. J Rheumatol 2008;35(8):1629-34. https://pubmed.ncbi.nlm.nih.gov/18528962/

13. Mont MA, Maar DC, Urguhart MW, Lennox D, Hungerford DS. Avascular necrosis of the humeral head treated by core decompression: a retrospective review. J Bone Joint Surg $\mathrm{Br}$ 1993;75-B(5):785-8. Crossref

14. Cushner MA, Friedman RJ. Osteonecrosis of the humeral head. J Am Acad Orthop Surg 1997;5(6):339-46. Crossref

15. Harreld KL, Marker DR, Wiesler ER, Shafiq B, Mont MA. Osteonecrosis of the humeral head. J Am Acad Orthop Surg 2009;17(6):345-55. Crossref 
16. Kennon JC, Smith JP, Crosby LA. Core decompression and arthroplasty outcomes for atraumatic osteonecrosis of the humeral head. J Shoulder Elbow Surg 2016;25(9):1442-8. Crossref

17. LaPorte DM, Mont MA, Mohan V, Pierre-Jacques $H$, Jones LC, Hungerford DS. Osteonecrosis of the humeral head treated by core decompression. Clin Orthop Relat Res 1998;(355):254-60. Crossref

18. Marker DR, Seyler TM, Ulrich SD, Srivastava S, Mont MA. Do modern techniques improve core decompression outcomes for hip osteonecrosis? Clin Orthop Relat Res 2008;466(5):1093-103. Crossref

19. Dines JS, Strauss EJ, Fealy S, Craig EV. Arthroscopic-assisted core decompression of the humeral head. Arthroscopy 2007;23(1):103.e1-4. Crossref

20. Harreld KL, Marulanda GA, Ulrich SD, Marker DR, Seyler TM, Mont MA. Small-diameter percutaneous decompression for osteonecrosis of the shoulder. Am J Orthop (Belle Mead NJ) 2009;38(7):348-54. https://pubmed.ncbi.nlm.nih. gov/19714276/

21. Hardy P, Decrette E, Jeanrot C, Colom A, Lortat-Jacob A, Benoit J. Arthroscopic treatment of bilateral humeral head osteonecrosis. Arthroscopy 2000;16(3):332-5. Crossref

22. Yajima $H$, Tamai $S$, Ono $H$, Kizaki K. Vascularized bone grafts to the upper extremities. Plast Reconstr Surg 1998;101(3):727-35. Crossref

23. Miyazaki AN, Silva LA, Sella GDV, Checchia CS, Simionato MC, Checchia SL. Articular reconstruction of the humeral head with autogenous allograft in the treatment of the osteonecrosis. Rev Bras Ortop 2017;53(1):113-7. Crossref
24. Scalise JJ, Miniaci A, lannotti JP. Resurfacing arthroplasty of the humerus: Indications, surgical technique, and clinical results. Tech Shoulder Elbow Surg 2007;8(3):152-60. Crossref

25. Soudy K, Szymanski C, Lalanne C, Bourgault C, Thiounn A, Cotten A, Maynou C. Results and limitations of humeral head resurfacing: 105 cases at a mean follow-up of 5 years. Orthop Traumatol Surg Res 2017;103(3):415-20. Crossref

26. Kesmezacar H, Ayhan E. Omuzda avasküler nekroz: Patogenez ve tedavi. TOTBID Derg 2010;9(1):24-34. http://dergi. totbid.org.tr/files/9_1/11.pdf

27. Hattrup SJ. Indications, technique, and results of shoulder arthroplasty in osteonecrosis. Orthop Clin North Am 1998;29(3):445-51. Crossref

28. Sperling JW, Cofield RH, Rowland CM. Neer hemiarthroplasty and Neer total shoulder arthroplasty in patients fifty years old or less: long-term results. J Bone Joint Surg Am 1998;80(4):464-73. Crossref

29. Mansat $P$, Huser $L$, Mansat $M$, Bellumore $Y$, Rongières M, Bonnevialle P. Shoulder arthroplasty for atraumatic avascular necrosis of the humeral head: nineteen shoulders followed up for a mean of seven years. J Shoulder Elbow Surg 2005;14(2):114-20. Crossref

30. Feeley BT, Fealy S, Dines DM, Warren RF, Craig EV. Hemiarthroplasty and total shoulder arthroplasty for avascular necrosis of the humeral head. J Shoulder Elbow Surg 2008;17(5):689-94. Crossref 